\title{
An Insight into Studies and Research on Corrosion in Petroleum Industries and Refineries
}

\author{
Sunil Jayant Kulkarni \\ Datta Meghe College of Engineering, Airoli, Navi Mumbai, Maharashtra, India \\ suniljayantkulkarni@gmail.com
}

\begin{abstract}
Chemical and petrochemical industries comprise of many equipments like storage tank, reactors, columns and jackets. These are often exposed to corrosive liquids and gases. Strong acids and gases such as carbon dioxide, sulphur oxides, organic vapours corrode the material and causes damage. It is desired to know the extent and mechanism of corrosion for proper and cost effective corrosion prevention method. Various investigators have carried out studies and research for corrosion, its measurement and prevention. Current review summarizes research on corrosion in petroleum, chemical and allied industries.
\end{abstract}

Keywords: inhibitors, corrosion control, biocides, prevention, monitoring, efficiency.

\section{INTRODUCTION}

Petroleum industries are backbone of the economical development of the countries .The crude exploration and its subsequent treatment and refining needs huge set up and equipments. The handling of various corrosive chemicals and gases in petrochemical industries calls for proper material of construction. The corrosion of the equipment is unavoidable due to continuous exposure of the material to the corrosive gases. Strong acids and gases such as carbon dioxide, sulphur oxides, organic vapours corrode the material and causes damage. Removal of various gases from exhaust stream can be carried out by absorption, electrostatic separators and adsorption [1,2,3,4,5,6]. Effluent water from these industries contains various chemicals. This water also needs to be treated from environmental and corrosion point of view. The organic and inorganic impurities and pollutants like phenol, acetic acid and organic matter can be removed by various chemical and biological methods $[7,8,9,10,11]$. Removal of impurities helps to reduce corrosion and also some of these chemicals can be reused after separation from water[12,13]. It is desired to know the extent and mechanism of corrosion for proper and cost effective corrosion prevention method. Various types of corrosions such as pitting, galvanic, localized etc. can take place. Various researchers have carried out research and studies on corrosion measurement and prevention. Current review summarizes research and studies on corrosion in petrochemical industries, its measurement and prevention.

\section{RESEARCH ON CORROSION IN PETROLEUM INDUSTRIES AND REFINERIES}

Zakaria et.al.discussed preventive strategies for corrosion control due to microbiologically induced activities [14]. They discussed various inhibitive strategies for controlling sulphur reducing bacteria. They compared the treatments by microwaves, ultraviolet, gamma radiation with biocide treatment. They tested six different biocides. They observed that all the biocides except nitrite were able to achieve complete inhibition. Rajeev et.al. investigated use of organic inhibitors for corrosion control of the oil well steels[15]. Hydrochloric acid is used for oil stimulation. It may induce severe corrosion attacks. According to them, gases such as $\mathrm{H}_{2} \mathrm{~S}, \mathrm{CO}_{2}$, and organic acids make the inhibition more complicated. They studied factors such as the type of reservoir rocks, the acids used for stimulation, the oil well equipments such as tubings and casings and the operating conditions which affect corrosion. It is important for the engineers, operators and workers to have corrosion awareness. Prabha et.al. discussed corrosion problems in petroleum industry and their solutions[16]. According to this discussion the corrosion occurs in petroleum industries in three stages namely production, condensate wells and sweet oil wells. According to these studies green inhibitors and biocidal inhibitors have gained momentum for corrosion prevention. Katundi et.al. characterized the corrosion behavior of stainless steel[17]. John et.al. assessed corrosion in oil refining and petrochemical processing[18]. They discussed the development of an information system used to manage corrosion 
of metals and alloys by high temperature gases. It is important to have proper corrosion information system. It is required to know corrosion mechanism in different complex gases. Also the information about corrosion in alloys for wide range of conditions is required. A report on internal corrosion in oil and gas pipelines was prepared by Nyborg[19]. He evaluated different corrosion models for $\mathrm{CO}_{2}$. It is important to know differences in these models in order to interpret the predictions. He observed high degree of uncertainty in these predictions. By increasing the $\mathrm{pH}$ of water phase, the corrosion rate in gas condensate pipelines can be substantially reduced. Ahmed studied fundamentals of corrosion control in oil industry[20]. His study analyzed the causes that lead to the high volume of corrosivity. According to these studies environmental conditions and accompanying crude acids, gases and production conditions in different stages affects corrosion behavior. Lu reviewed challenges due to erosion corrosion [21]. Protective surface film is effective way of reducing corrosion in metals. But Erosion fluids can damage the protective film and remove small pieces of material. This increases penetration rate significantly. The fluid-induced mechanical forces or flowing-enhanced dissolution can damage the protect film. The conjoint action of erosion and corrosion takes place. Proper design, material selection and chemical control can help in minimizing erosion corrosion. Das studied corrosion effects of inhibitor on steel due to brine [22]. He used weight loss measurement technique. He carried out experiments in an autoclave at varying temperature and a fixed partial pressure of carbon dioxide. He used imidazoline as corrosion inhibitor. They found that addition of $40 \mathrm{ppm}$ of inhibitor showed the higher efficiency due to the formation of more adhered and protective film over the metal surface. Okiet.al. studied corrosion monitoring in the oil pipeline industry[23]. They presented studies on current knowledge on corrosion and monitoring of internal and external corrosion phenomena in the transmission and distribution pipelines in petroleum industry. According to them, side stream monitoring technique can be used for direct and accurate measurements of internal corrosion of pipelines. Naphthenic acid corrosion in a visbreaker unit was studied by $\mathrm{O}^{\text {ec Kane }}$ et.al.[24]. The corrosion to an amount of $0.8 \mathrm{~mm} / \mathrm{month}$ was observed by them. They also observed that shell corrosion was limited to the vicinity of four trays situated approximately two thirds of the way up the column.

\section{Conclusion}

Various investigators have carried out studies on various types of corrosion, its mechanism, measurement and prevention. Various types of bacteria can reduce the materials such as sulphur. Use of various inhibitors helps in reducing corrosion in oil well streets. Factors such as type of reservoir rocks, the acids used for stimulation, the oil well equipments affect the corrosion in petroleum exploration. Green inhibitors and biocidal inhibitors have gained momentum for corrosion prevention. It can be concluded that, it is important to know the mechanism of corrosion for selecting proper corrosion control method. Also proper treatment of boiler water, process water and effluent water can help in reducing the corrosion.

\section{REFERENCES}

[1] Sunil J. Kulkarni, Nilesh L. Shinde, 2014, "A Review on Hydrogen Sulphide Removal from Waste Gases", International Journal of Advanced Research in Science, Engineering and Technology, 1(4), PP.187-189.

[2] Tanmay Uttam Gound, Veena Ramachandran, Sunil Kulkarni, 2014, "Various Methods To Reduce $\mathrm{SO}_{2}$ Emission- A Review", International Journal Of Ethics In Engineering \& Management Education, 1(1), PP.1-6.

[3] Veena Ramachandran, Tanmay Uttam Gound, Sunil Kulkarni, 2014, "Biofiltration for Waste Gas Removal- A Review", International Journal of Ethics in Engineering and Management Education, 1(2), PP.8-13.

[4] Sunil Jayant Kulkarni, Ajaygiri Kamalgiri Goswami,2014, "Adsorption For Waste Gas Treatment: A Short Review", International Journal For Research In Applied Science \& Engineering Technology, 2(12), PP.513-514.

[5] Sunil Jayant Kulkarni, Ajaygiri Kamalgiri Goswami and Nilesh Shinde, 2015, "Treatment and Recovery for Flue Gases: a Review", International Journal of Research, 2(6), PP.515-519.

[6] Sunil Jayant Kulkarni, 2015, "Advancements, Research and Challenges in Reactive Adsorption: A Review", International Journal of Research, 2(1), PP.477-480.

[7] Sunil J. Kulkarni, 2013, "Removal Of Organic Matter From Domestic Waste Water By Adsorption", International Journal of Science, Engineering and Technology Research, 2(10), PP.1836-1839. 
[8] Sunil J. Kulkarni, Ajaygiri K. Goswami, 2013, "Adsorption Studies for Organic Matter Removal from Wastewater by Using Bagasse Flyash in Batch and Column Operations", International Journal of Science and Research, 2(11), PP.180-183.

[9] Madhura Chincholi, Priyanka Sagwekar, Charmi Nagaria, Sunil Kulkarni, Sonali Dhokpande, 2014, "Removal Of Dye By Adsorption On Various Adsorbents: A Review", International Journal of Science, Engineering and Technology Research, 3(4), PP.835-840.

[10] Mrunmai Joshi, Nikita More, Deepa Gaikwad, Sunil Kulkarni, 2014, "Removal of Acetic Acid from Wastewater by Low Cost Materials- a Review", International Journal of Science, Engineering and Technology Research, 3(10), PP.2630-2632.

[11] Sunil J. Kulkarni, Jayant Prabhakarrao Kaware, 2015, "Phenol removal from effluent by rice husk carbon: batch and column studies", International Journal of Environmental Engineering, 7(2), PP. 131-142.

[12] Sunil Kulkarni, 2014, "Recycle and Reuse of Water- A Review", International Journal of Research, 1(11), PP. 802-805.

[13] Kirsten Exall, 2004, "A Review of Water Reuse and Recycling, with Reference to Canadian Practice and Potential: 2. Applications", Water Qual. Res. J. Canada, 39(1), PP.13-28.

[14] Abeer E. Zakaria, H. M. Gebreil And Naglaa M. Abdelaal, 2012, "Control Of Microbiologically Induced Corrosion In Petroleum Industry Using Various Preventive Strategies, Arab Journal Of Nuclear Sciences And Applications, 45(2), PP.460-478.

[15] P. Rajeev, A. O. Surendranathan, Ch. S. N. Murthy, 2012, "Corrosion Mitigation Of The Oil Well Steels Using Organic Inhibitors - A Review”, J. Mater. Environ. Sci., 3(5), PP.856-869.

[16] S. Santhana Prabha, R. Joseph Rathish, R.Dorothy, G.Brindha, M.Pandiarajan, Abdulameed AlHashem, And S.Rajendran, 2014, "Corrosion Problems In Petroleum Industry And Their Solution”, Eur. Chem. Bull., 3(3), PP.300-307.

[17] D. Katundi, A. Tosun-Bayraktar, E. Bayraktar, D. Toueix, 2010, "Corrosion Behaviour Of The Welded Steel Sheets Used In Automotive Industry, Journal Of Achievement In Material And Manufacturing Engineering, 38(2), PP.146-153.

[18] 18. Randy C. John, Arthur D. Pelton, Arthur L. Young, William T. Thompson, 2004, "Assessing Corrosion In Oil Refining And Petrochemical Processing”, Materials Research, 7(1), PP.163171.

[19] Rolf Nyborg, 2005, "Controlling Internal Corrosion In Oil And Gas Pipelines", Business Briefing: Exploration \& Production: The Oil \& Gas Review, 2, PP.70-72.

[20] Mohamed Mustafa Elnour Ahmed, 2014, "Fundamentals Of Corrosion Mitigations In Oil Industry", Sudan Engineering Society Journal, 60(1), PP.23-30.

[21] Baotong Lu, 2013, "Erosion-Corrosion In Oil And Gas Production", Research And Reviews In Materials Science And Chemistry, 2(1), PP.19-60.

[22] Ghanshyam Das, 2014, "Inhibiting Effects Of Organic Inhibitor on Corrosion Of Steel In 3.5\% Brine Solution", Int. J. Mech., 3(3),PP.165-171.

[23] Makanjuola Oki, 1adeolu Adesoji Adediran, Paul. A . L. Anawe, 2015, "Corrosion Monitoring In The Oil Pipeline Industry", Journal Of Multidisciplinary Engineering Science And Technology, 2(1), PP.299-303.

[24] J.M. O"Kane, T. F. Rudd, D. Cooke, F.W.H. Dean \& S.W. Powell, 2010, "Detection And Monitoring Of Naphthenic Acid Corrosion In A Visbreaker Unit Using Hydrogen Flux Measurements", Nace Internation Corrosion Conference And Expo. ,Nace International, Publications Division, 1440 South Creek Drive, Houston, Texas, PP.1-15.

\section{AUTHOR's BIOGRAPHY}

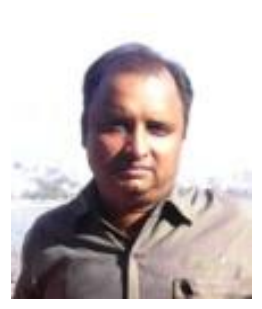

Mr. Sunil J. Kulkarni, has completed his Masters in Chemical Engineering from Tatyasaheb Kore Institute of Engineering and Technology, Warananagar in 2006. $\mathrm{He}$ is currently pursuing his $\mathrm{phD}$ in chemical engineering. He is working as Assistant Professor in Chemical Engineering Department of Datta Meghe College of Engineering, Airoli, Navi Mumbai, India. The author has 16 years of experience in teaching and research. He has published 113 international review and research papers and presented 15 research papers in international conferences. His area of research includes adsorption, environmental engineering and catalysis. He is editorial board member of more than 25 international journals and reviewed many international papers. 